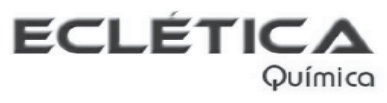

www.scielo.br/eq

Volume 29, número 2, 2004

\title{
Application of differential scanning calorimetry in hair samples as a possible tool in Forensic Science
}

\author{
E. Y. Ionashiro ${ }^{1}$; T. S. R. Hewer ${ }^{1}$; F. L. Fertonani ${ }^{1}$; E. T. de Almeida ${ }^{2}$; \\ M. Ionashiro ${ }^{1}$ \\ ${ }^{1}$ Unesp - Instituto de Química, R-Professor Francisco Degni s/n, Caixa postal- 355 - CEP-14800-900 - Araraquara - SP \\ ${ }^{2}$ Universidade Católica de Brasília (UCB), Curso de Química, QS-07, Lote 01, EPCT, Águas Claras, CEP-71966-700, Brasília-DF \\ Correspondingauthor: massaoi@iq.unesp.br
}

\begin{abstract}
The Differential Scanning Calorimetry (DSC) was used to study the thermal behavior of hair samples and to verify the possibility of identifying an individual based on DSC curves from a data bank. Hair samples of students and officials from Instituto de Química de Araraquara, UNESP were obtained to build up a data bank. Thus to sought an individual, under incognito participant of this data bank, was identified using DSC curves.
\end{abstract}

Keywords: Differential Scanning Calorimetry (DSC); hair; Forensic Science.

\section{Introduction}

For many years several techniques such as chromatography and absorbance techniques, have been successfully employed to determine poisonous substances in human organism that are accumulated in the hair tissue, however, there are a few studies using the DSC techniques. [1,2,3]. The hair tissue has the property to incorporate some endogenous and exogenous factors from the environment, that helps in the determination of some intoxication cases like the intoxication by heavy metals, drugs use [4] and some nutritional information from victims. The hais tissue has the property of biological monitor [1] because it is a human organism excretory system. At this way, all human metabolism's excretion are proteins (80\%), water (15\%), lipids (2\%) and the remaining are minerals. The spiral form of a-keratin is that gives the hair sustentations, which is, immerse in the matrix and made of proteic cells rich in tyrose and sulfur. The hair color is related to the melanin quantity, human pigment that has a photo protector function, at this way darker hair has major melanin quantity.

The thermal analytical techniques, as Differential Thermal Analysis (DTA) and Differential Scanning Calorimetry (DSC) has been used with success in the characterization and identification of several products or materials as mammoth's ivory or elephant's ivory [5]; soils [6]; wool [7], etc.

The aim of this study is to verify the potentiality of the DSC techniques to identify an individual through his hair DSC curves with aid of a bank data.

\section{Experimental}

The hair samples from the posterior part from head were collected between students and officials from Instituto de Química de Araraquara, UNESP, searching to obtain samples from different ethnic groups (Caucasoid, Negroid and Asiatic). About $100 \mathrm{mg}$ of sample from each person was divided in two parts. One of them was 
maintained in a data bank and the other for thermal study. The samples which were sent to the thermal study was also divided in two parts, one of them was washed with EXTRAN 5\% (v/v) solution in ultrasonic system and stored in a desiccator over anhydrous calcium chloride while the other part was maintained without previous treatment.

\section{Results and discussions}

Figures 1 and 2 shown the DSC curves of hair samples from three different ethnic groups without previous treatment. These curves show four thermal events between 30 and $600^{\circ} \mathrm{C}$. The endothermic event between 50 and $130^{\circ} \mathrm{C}$, with minimal temperature that vary between 60 and $80^{\circ} \mathrm{C}$, is attributes to water elimination from capilar tissue. The endothermic peak observed at $230^{\circ} \mathrm{C}$ is attributed to the melting of the a-form crystallites in human hair keratin [8].

A)

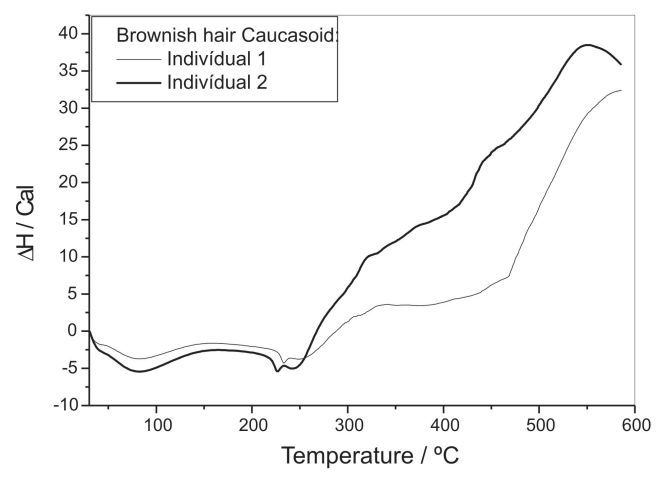

B)

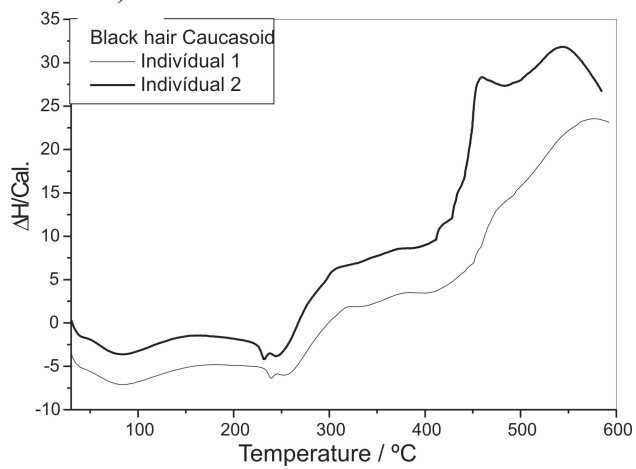

Figure 1 - DSC curves from the same ethnic group: $\mathrm{T}_{\mathrm{i}}=30^{\circ} \mathrm{C}$; $\mathrm{T}_{\mathrm{f}}=600^{\circ} \mathrm{C} ; \mathrm{b}=20^{\circ} \mathrm{C} \mathrm{min}^{-1} ;$ Air Flow $\left.=100 \mathrm{~mL} \mathrm{~min}^{-1} ; \mathrm{A}\right)$ Brownish hair caucasoids; B) Black hair caucasoids.
A)

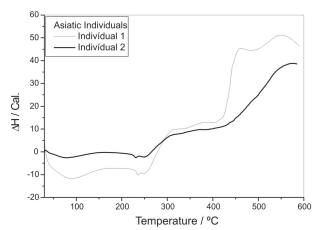

B)

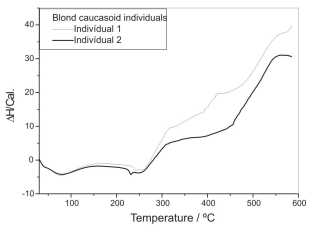

C)

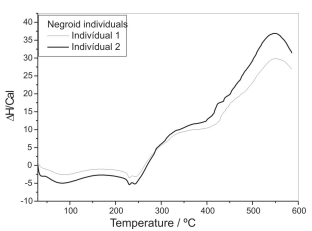

Figure 2 - DSC curves from the same ethnic groups: $T_{i}=$

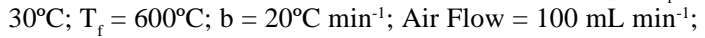
A) Asiatic Individuals; B) Blond Individuals; C) Negroid Individuals

The isotherm observed above $300^{\circ} \mathrm{C}$, which suggests several overlapping events, is attributed to the hair's organic matter oxidation.

A comparison between these hair DSC curves shows that there are not any similarities that can be attributed to ethnic factors. Nevertheless, in spite of the great similarity observed among themselves, the hair of each individual shows DSC curve with peculiar characteristics.

The DSC curves for hair samples, which were washed, and the samples, which were studied without previous treatment, are shown in Fig. 3. A great similarity is observed in the profile of these curves, nevertheless the melting of the a-form crystalites in human hair keratin, occurs at the same temperature indicating that the melanin quantity present in hair do not change its basic structure. In spite of the great similarity in the profile of these curves slight differences, are observed above $300^{\circ} \mathrm{C}$.

The DSC curves of hair samples, which were maintained in a data bank, without previous treatment, are shown in Fig 5.

These curves were obtained to verify the possibility to identify an individual participant of the data bank, since each person's hair showed a characteristic DSC curve. Thus, one month after the hair have been collected, a new sample from an anonymous person from the data bank was 
collected. The overlaying of these curves with the data bank, that correspondent the Fig. 6 allowed to identify this person.
A)

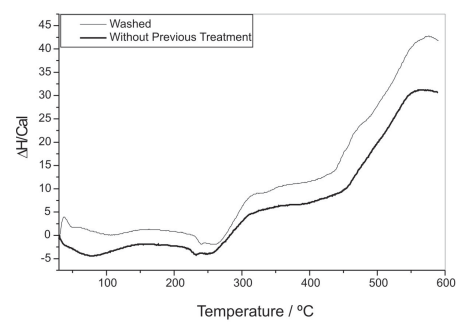

B)

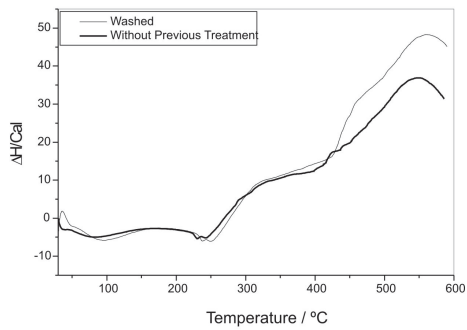

C)

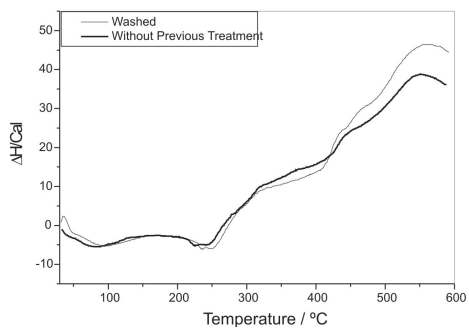

Figure 3 - Comparison between the washed and non washed hair DSC curves: $b=20^{\circ} \mathrm{C} \mathrm{min}^{-1}, \mathrm{~T}_{\mathrm{i}}=30^{\circ} \mathrm{C} ; \mathrm{T}_{\mathrm{f}}=600^{\circ} \mathrm{C}$; Air Flow $=$ $100 \mathrm{~mL} \mathrm{~min}^{-1}$; Washing treatmentt with Neutral EXTRAN 5\%. A) Blond caucasoid individual; B) Negroid Individual; C) Black hair individual

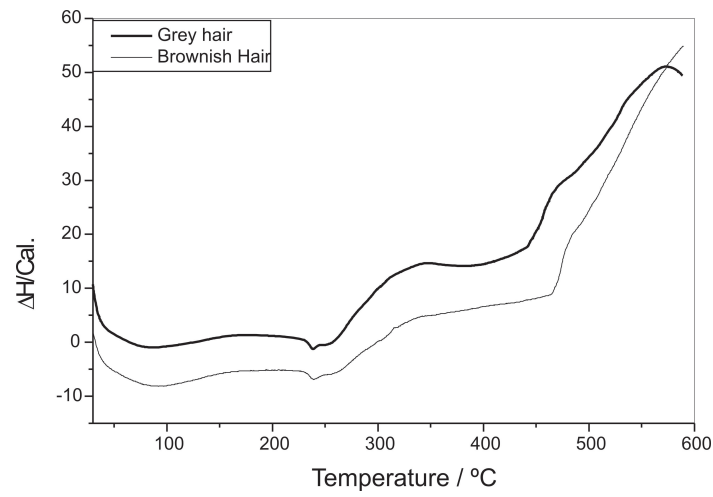

Figure 4 - Comparison between the DSC curves of the brownish hair and Grey hair from same individual; $\mathrm{T}_{i}=30^{\circ} \mathrm{C}$; $\mathrm{T}_{\mathrm{f}}=600^{\circ} \mathrm{C}, \mathrm{b}=20^{\circ} \mathrm{C} \mathrm{min}^{-1}$; Air Flow $=100 \mathrm{~mL} \mathrm{~min}^{-1}$.

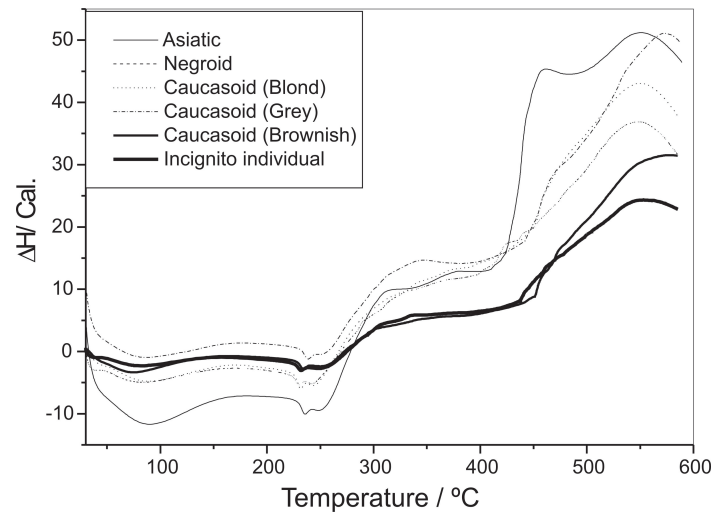

Figure 5 - Incognito identification and the data bank DSC

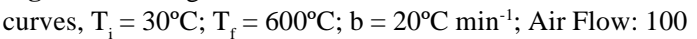
$\mathrm{mL} \min ^{-1}$.

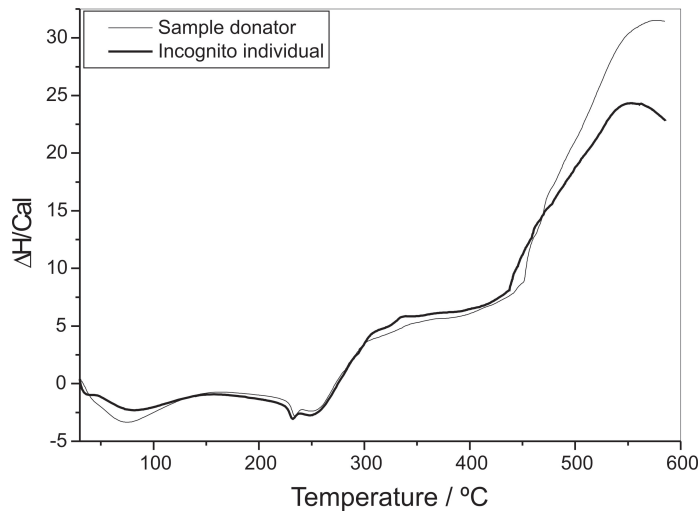

Figure 6 - Incognito individual and donator individual DSC

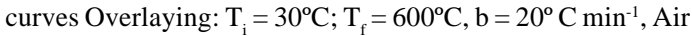
Flow: $100 \mathrm{~mL} \mathrm{~min}^{-1}$

\section{Conclusions}

The results obtained in the present paper, showed that the hair DSC curves do not allow to identify the ethnic group of the person. Although the DSC curves show a great similarity among themselves, the hair from each individual, showed DSC curves with peculiar characteristics, which allowed to identify a person from this data bank.

Recebido em 09/02/04

Aceito em 10/05/04 
E. Y. Ionashiro, T. R. S. Hewer; F. L. fertonani, E. T. de Almeida, M. Ionashiro. Aplicação da Calorimetria Exploratória Diferencial (DSC) em amostras de cabelo como possível ferramenta em Ciência Forense.

Resumo: A calorimetria Exploratória Diferencial (DSC) foi utilizada para estudar o comportamento térmico de amostras de cabelo e verificar a possibilidade de identificar um indivíduo com base nas curvas DSC de um banco de dados. Amostras de cabelo de estudantes e funcionários do Instituto de Química de Araraquara - UNESP, foram obtidas para construir um banco de dados. Procurou-se assim identificar de um indivíduo sob incógnita, utilizando-se a curva DSC deste banco de dados.

Palavras-chave: Calorimetria Exploratória Diferencial (DSC), Cabelo, Ciência Forense.

\section{References}

[1] M. T. W. D. Carneiro, C. L. P. Silveira, N. Miebeley, Quim. Nova, 25 (2002) 37.

[2] D. Pozebon, V. L. Dressler and A. J. Curtis, Quim. Nova, 22 (1999( 838.

[3] J. F. Alder, A. J. Samuel and T. S. Wst, Anal. Chim Acta, 87 (1976) 313.
[4] Y. Gaillard, G. Pepin, J. Chromatogr. A. 762 (1997) 251.

[5] F. Burragato, S. Materazzin, R. Curini, G. Ricci, Forensic Sci. Int. 96 (1998) 189.

[6] S. Seta, Forensic Sci. Int. 80 (1996) 109.

[7] A. Riga, Thermochim. Acta, 324 (1998) 151.

[8] J. Cao, Thermochim. Acta, 335 (1999) 5. 